\title{
Irradiated Volume
}

National Cancer Institute

\section{Source}

National Cancer Institute. Irradiated Volume. NCI Thesaurus. Code C112911.

A tissue volume which receives a dose that is considered significant in relation to healthy tissue tolerance. 